\section{So-called idiopathic scoliosis - disfiguring deformity in children, pain problems in adults. Information about biomechanical etiology, classification and therapy}

\author{
Tomasz Karski* \\ Professor, MD, Vincent Pol University, Lublin, Poland
}

\section{Abstract}

In the article presented the etiology of the so-called idiopathic scoliosis (Adolescent Idiopathic Scoliosis [AIS]), new classification, there are given rules of therapy and causal prophylaxis. This knowledge is based on observations from 1984, but essentially from the years $1995-2007$. In 2001 it was given the first description in classification - "S" scoliosis in $1^{\text {st }}$ group / type and " $C$ " and "S" scoliosis in $2^{\text {nd }} \mathrm{A} / \mathrm{B}$ group and types, in 2004 "I" scoliosis in $3^{\text {rd }}$ group / type.

\section{Introduction}

Etiology of the so-called idiopathic scoliosis was a secret for over two thousand years. In Poland in 1995 - 2007 I described the etiology, and was then given new classification, rules of new therapy and causal prophylaxis [1-20].

\section{Epidemiology of scoliosis and etiological factors, material}

In every country more than $12 \%$ of the children are endanger of scoliosis [21-37]. In my material it is 2500 children from the years 1984 - 2020 in observation and in treatment. Spine deformity is connected with two biomechanical factors: $1 /$ the habit of standing 'at ease' on the right leg (!), 2/the gait. These two factors are connected with the asymmetry hip movements. There is a restriction of adduction and internal rotation of the right hip, which enable an easier standing on the right leg and change the parameters of the gait. Every type of scoliosis start in their development at age of 2 - 3 years.

\section{Why is there restriction of movement of the right hip?}

Asymmetry of the movement of the hips is one of the eight symptoms of the "Syndrome of Contracture and Deformities (SofCD) according to Prof. Hans Mau and Lublin observations $[31,32]$. In SofCD there are three various "models of the hips movements" and as a result three groups and four types of the so-called idiopathic scoliosis according to the Lublin classification.

\section{Causes of scoliosis}

\section{More Information}

*Address for Correspondence: Tomasz Karski, Professor, MD, Vincent Pol University, Lublin, Poland, Tel: +48 604933 234; Email: tmkarski@gmail.com; t.karski@neostrada.pl

Submitted: 11 February 2020

Approved: 09 March 2020

Published: 10 March 2020

How to cite this article: Karski T. So-called idiopathic scoliosis - disfiguring deformity in children, pain problems in adults. Information about biomechanical etiology, classification and therapy. J Adv Pediatr Child Health. 2020; 3 : 016-020.

\section{DOI: 10.29328/journal.japch.1001011}

Copyright: (c) 2020 Karski T. This is an open access article distributed under the Creative Commons Attribution License, which permits unrestricted use, distribution, and reproduction in any medium, provided the original work is properly cited.

Keywords: So-called idiopathic scoliosis Biomechanical etiology; Classification; Therapy; Causal prophylaxis

Check for updates

OPEN ACCESS

In the development of the so-called idiopathic scoliosis biomechanical causes play the role - permanent standing 'at ease' on the right leg and "distortion movements" of intervertebral joints by every step as "compensatory movement in situation of fully restricted movement of the right hip" - see next chapter about classification (Figures 1-3). Additionally in the development of spine deformity - Minimal Brain Dysfunction (MBD) play role - extension contracture of the trunk, anterior tilt of the pelvis and laxity of the joints (Figure 4 a,b,c). The spine deformity in all types starts to develop at the age of $2-3$ years. The first symptoms in " $S$ " scoliosis in $1^{\text {st }}$ type are at age of $5-7$ years and the first symptoms are not curves but stiffness of spine in Th 6 - Th 12 part of the thoracic spine. In "C" $2^{\text {nd }} /$ A type and in "S" $2^{\text {nd }} / \mathrm{B}$ types the deformity appear at the age of $10-12$ years.

In both of these type of deformity the main etiological cause is "standing 'at ease' on the right leg" - and if this habit persist over all years of life - and is one of the main causes of back pain in adults patients [11,13-18].

New classification. Three groups and four types of scoliosis

Scoliosis “S": $1^{\text {st }}$ etiopathological group (epg), 3D - double 
curve (Figure 1). Stiff spine. Rib hump on the right side of the thorax. Connection with "gait" and permanent "standing 'at ease' on the right leg". Beginning of deformity in $2-3$ year of life. Clinical symptoms appear at the age of $5-6$ years.

Scoliosis “C": 2 ${ }^{\text {nd }} /$ A epg - 1D or 2D - one curve - lumbar left convex. (Figure 2). Spine flexible. Connection with permanent standing 'at ease' on the right leg. Beginning of deformity at the age of $2-3$ years. Clinical symptoms appear at the age of $8-10$ years. In adults heavy pain syndromes.

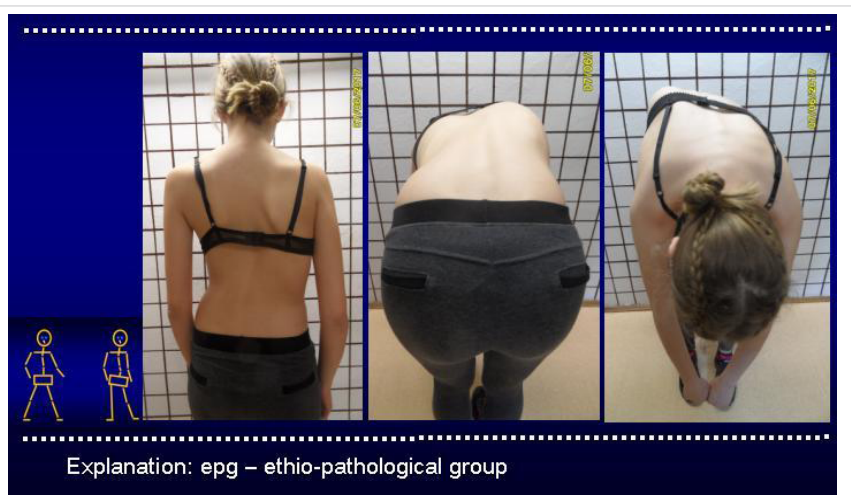

Figure 1: Three groups and four types of the so-called idiopathic scoliosis. Scoliosis "S" in 1st.epg group \& type. Two curves. Gibbous. Stiff spine. Specific model of hips movements [see Figure 5(A) (B)]. Causal influence: "gait" and "standing". Explanation: epg - ethio-pathological group.

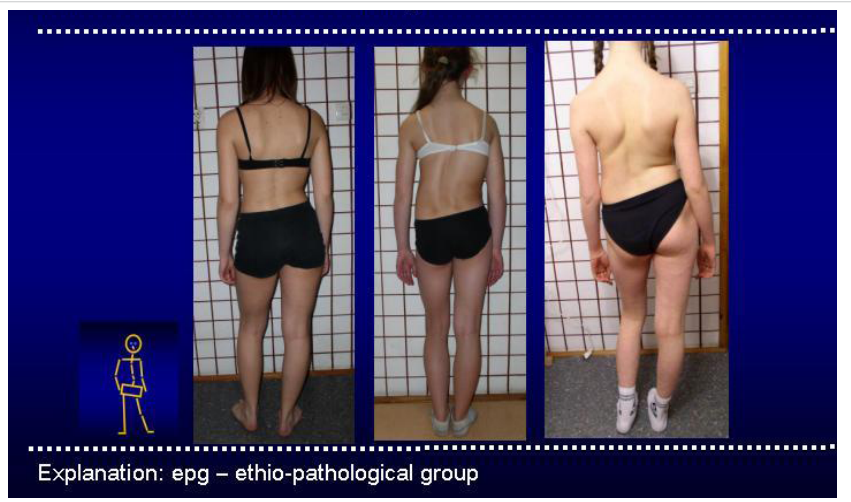

Figure 2: Three groups and four types of the so-called idiopathic scoliosis. Scoliosis " $C$ " $\&$ " $S$ " in $2^{\text {nd }} / A / B$ epg group \& types. One or two curves. Flexible spine. Specific model of hips movements [see Figure $5(A)(B)$ ] plus laxity in " $\mathrm{S}$ " scoliosis. Causal influence: "standing".

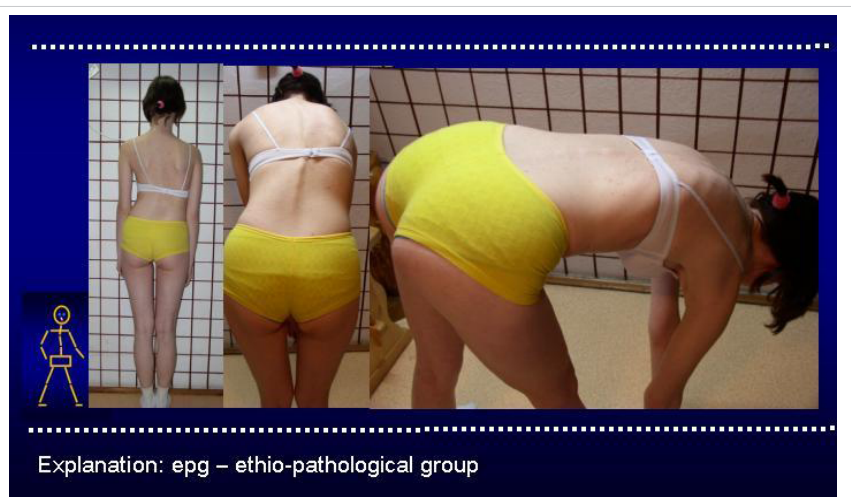

Figure 3: Three groups and four types of the so-called idiopathic scoliosis. Scoliosis "I" in $3^{\text {rd }}$. epg group \& type. No curves or small. Stiff spine. Specific model of hips movements [see Figure 5 (A) (B)]. Causal influence "gait".

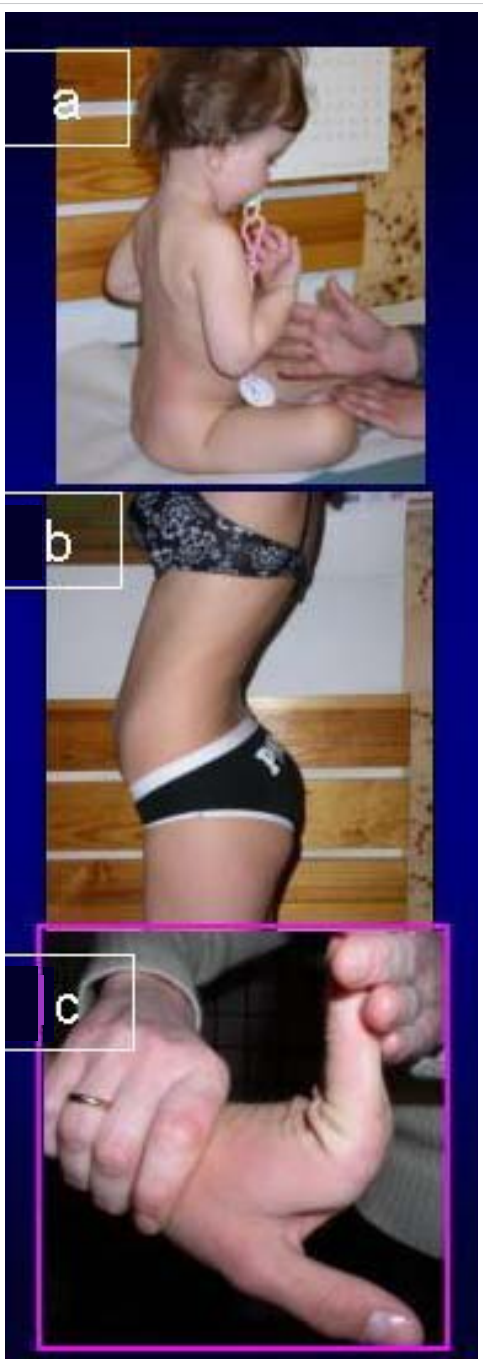

Figure 4: Additional indirect causes in development of the so-called idiopathic scoliosis. Symptoms of Minimal Brain Dysfunction [MBD]. (4a) Extension contracture of spine. (4b) Anterior tilt of pelvis and hiperlordosis of the lumbar spine. (4c) Laxity of joints.

Scoliosis “S": 2 nd $^{\text {B }}$ epg 2D or 3D- two curves. (Figure 2). Connection with permanent standing 'at ease' on the right leg and additionally with laxity of joints or / and harmful previous exercises. Beginning of deformity at the age of 2-3 years. Clinical symptoms appear at the age of $10-12$ years. In both types " $\mathrm{C}$ " and " $\mathrm{S}$ " in $2^{\text {nd }} / \mathrm{A} / \mathrm{B}$ group - the spine is flexible.

Scoliosis “I": $3^{\text {rd }}$ epg - 2D or 3D. (Figure 3). Specific model of hip movements. Deformity has the form of a stiff spine. No curves or small ones. The cause is gait only. Such "spine deformity" was until 2004 never included and classified as "scoliosis". Beginning of deformity at the age of 2-3 years. Clinical symptoms - "stiffness of the spine in children" and "permanent pain in adults". Why stiffness? In situations of maximal limited adduction, internal rotation and very often also extension of the right hip - appears compensatory movement in the pelvis and in the spine with every step during gait. This rotation movement in inter-vertebral joints is bigger than normal and has the character of "distortion", as a result causes fibrosis and "stiffness". To discover scoliosis we must use not only old, but also new tests (Figures 5,6). 


\section{Therapy and prophylaxis}

The therapy of scoliosis must undergo the metamorphosis - the old therapy with incorrectly exercises must be only in history. What kinds of rehabilitation exercises should be applied? Only - stretching exercises - giving symmetry of movements and next symmetry of growth and the development of the pelvis and the spine. At first - we should restore the full movement of the right hip and full movement of the spine. The best way to do this is by stretching exercises like karate, taekwondo, aikido, kung fu and others (Figure 7). Such treatment gives good results in every case, but therapy must be carried out in the early years of a child's life age (Figures 8,9). Now - it is my ethical obligation to inform - that - flexion exercises for the spine in scoliosis in Poland many years ago were introduced by Prof. Stefan Malawski (Warsaw, Otwock). But at this time the influence of the etiological factors: "standing 'at ease' on the right leg" and "gait" had not discovered.

\section{Causative prophylaxis}

The causative prophylaxis we should introduce in all countries for every child. To discover the danger of scoliosis - we should use not only old but also new tests (Figures 5,6).

\section{List of tests}

1. We should define the manner of standing 'at ease' on the left or on right leg.

2. Test of adduction of both hips - in extension position of the joints.

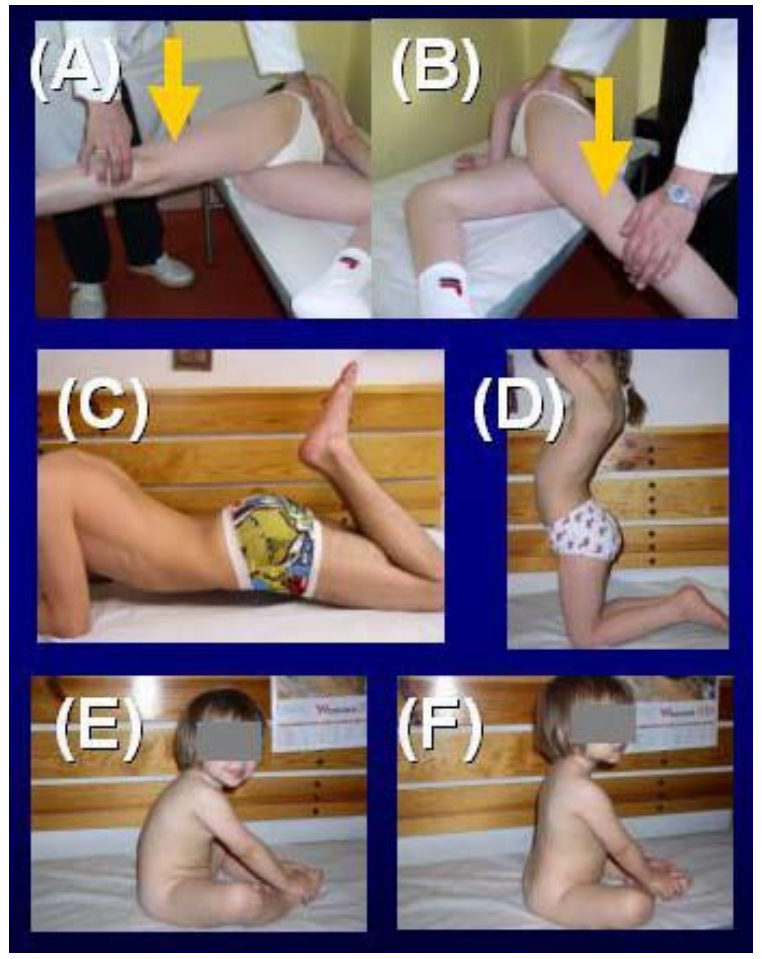

Figure 5: Tests in scoliosis to detect the asymmetry in position \& function of joints. $(A, B)$ Adduction test (Ober test). (C) Ely Duncan (Thom, Staheli) test. (D) Kneeling test. (E, F) Sitting test.

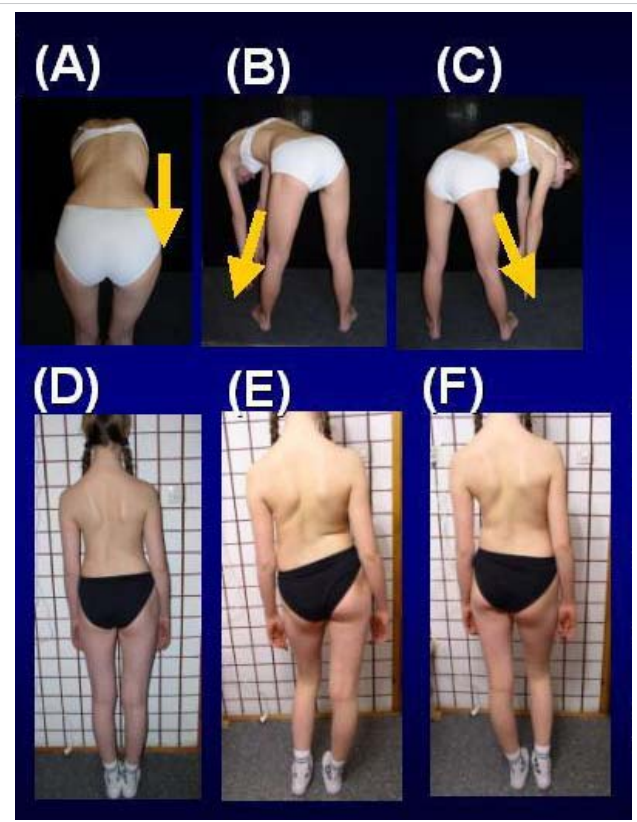

Figure 6: Tests in scoliosis to detect the asymmetry in position \& function of joints. (A) Adams test. (B) (C) Lublin test. (D) (E) (F) Standing test.

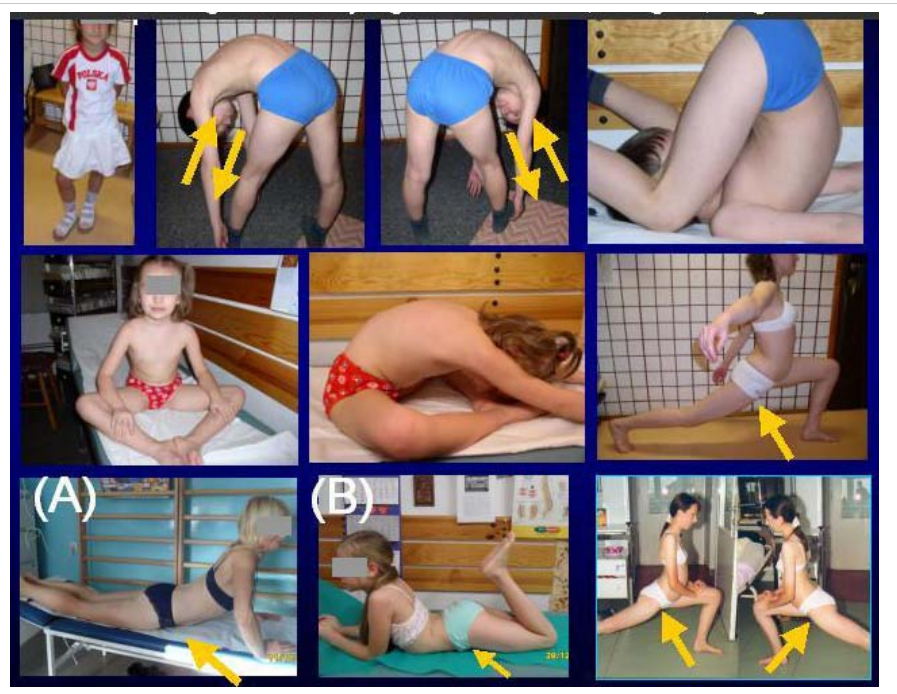

Figure 7: Proper - stretching exercises in therapy of the so-called idiopathic scoliosis. Standing on the lefty leg. Karate. Aikido, Kung Fu, Yoga.

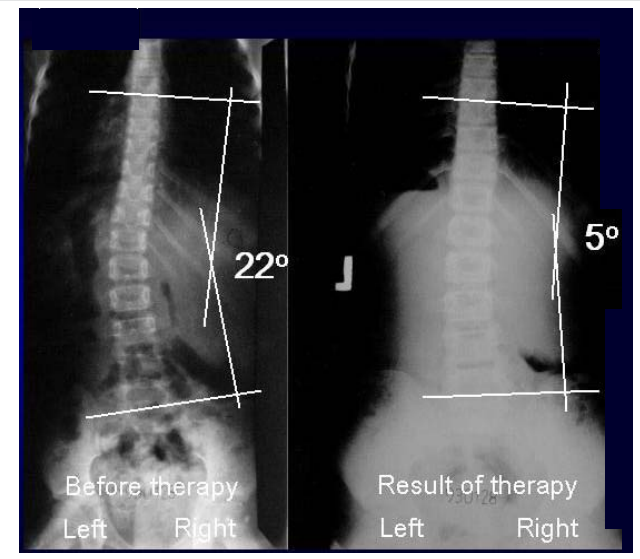

Figure 8: Child Weronika, 10 years old. History 930128. Scoliosis " $C$ " in $2^{\text {nd }} / A$ epg group \& type. 4 years new therapy. In program: (1) standing 'at ease' only on the left leg, (2) bending exercises forward and to the left side many times per day, (3) sport in school, karate, (4) rest \& sleeping in embryo position on right side. 


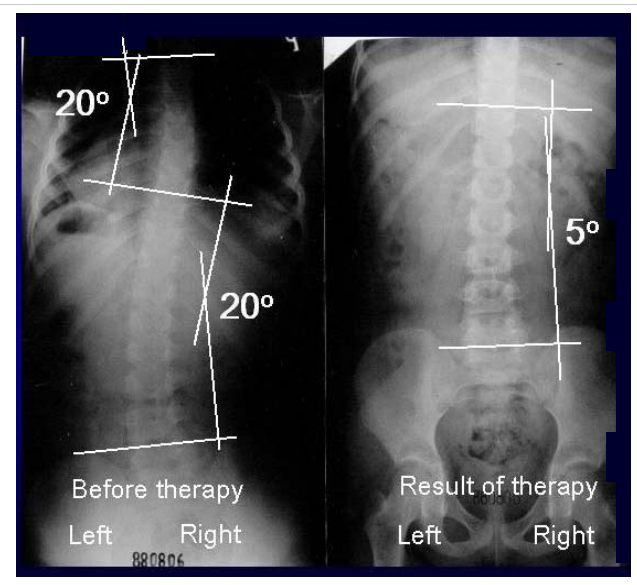

Figure 9: Child Anna, 12 years old. History 880806. Scoliosis " $S$ " in $2^{\text {nd }} / B$ epg group \& type. 2 years and 6 month the new, proper therapy. (1) standing 'at ease' only on the left leg, (2) bending exercises forward and to the left side many times per day, (3) sport at school, plus karate, (4) resting \& sleeping in the embryo position.

3. Adams - Meyer test - in other words - bending test for scoliosis

4. Lublin test - side bending test for scoliosis.

5. Elly - Duncan (or Staheli, or Thom) test to discover the anterior tilt of pelvis - due to flexion contracture of the hips - resulting - hiperlordosis of the lumbar spine.

6. Kneeing test (similarly to point 5) - to discover the anterior tilt of the pelvis - flexion contracture of the hips - and hiperlordosis of lumbar spine.

\section{Prophylactic recommendations against scoliosis in points}

A. Standing 'at ease' only on the left leg.

B. Sitting relax - never straight up.

C. Sleeping in the embryo position.

D. Active participation in sport at school and additionally in clubs - the best are karate, kung fu, taekwondo, aikido, yoga.

E. Physiotherapy/Kinesio-therapy to obtain full, symmetrical movement of both hips and movement of the spine flexion, deviation, rotation. Especially important is to recover the full adduction and internal rotation movement of the right hip.

\section{Discussion and remarks}

Information to this problem is presented on the Website www.ortopedia.karski.lublin.pl from 2006. In Poland, in the years 1995 - 2009 I have given many lectures about "the problem of scoliosis", but till now "the explanation of etiology and the rules of new therapy is not understood nor accepted". Why?

My lectures have also been presented five times abroad at the International Research Society for Spinal Deformity [IRSSD] Meetings [2002 - 2012] and twice at the Society on Scoliosis Orthopedic and Rehabilitation Treatment [SOSORT]
Congresses [2006 - 2014]. Here I can repeat the question why the new knowledge has not been admitted?

Here - with a very big pleasure I can state - an exception that scientists and many Journals in the USA are very interested in new knowledge. Professor Martha Hawes and Professor Jan Stokes from the USA confirm this new knowledge many years. Similarly - Professor John Sevastik from Sweden and Professor Stefan Malawski from Poland - understood my explanation of the biomechanical etiology of the so-called idiopathic scoliosis.

Children all over the world are waiting for prophylaxis and it depend of all orthopedics surgeons, rehabilitations doctors, as well as pediatrician decisions. My appeal is - we should start with the prophylaxis of scoliosis now.

\section{Conclusion}

1. In all the years of my orthopedic activity and search for scoliosis, the biomechanical etiology of the so-called idiopathic scoliosis was confirmed.

2. Development of scoliosis and the types of spine deformity are connected with pathological "model of hip movements" [38] and the function - "standing 'at ease' on the right leg" and "gait".

3. Restricted range of movements in the right hip is connected with the "Syndrome of Contractures and Deformities" according to Prof. Hans Mau and Lublin observations.

4. Every type of scoliosis starts to develop at the age of 2-3 years. The infantile scoliosis in not the "So-Called Idiopathic Scoliosis".

5. There are three groups and four types of scoliosis (see classification in text).

6. The causal prophylaxis of scoliosis is possible and should be introduced in every country.

7. The rules of prophylaxis for all children are:

a. Standing 'at ease' on the left leg,

b. Sitting in a relaxed position,

c. Sleeping in an embryo position,

d.Active participation in sports in school and at home every day,

e. Especially beneficial sports are: karate, taekwondo, aikido, kung fu and other similar sports.

\section{Acknowledgement}

I would like to express my many thanks to Mr. David Poynton for the corrections of this article. 


\section{References}

1. Karski T. Etiology of the so-called "idiopathic scoliosis". Biomechanical explanation of spine deformity. Two 272 groups of development of scoliosis. New rehabilitation treatment. Possibility of prophylactics, Studies in 273 Technology and Informatics, Research into Spinal Deformities. 2002; 91: 37-46.

2. Karski T, Kalakucki J, Karski J. "Syndrome of contractures" (according to $\mathrm{Mau}$ ) with the abduction contracture of the right hip as causative factor for development of the so-called idiopathic scoliosis. Stud Health Technol Inform. 2006; 123: 34-39.

PubMed: https://www.ncbi.nlm.nih.gov/pubmed/17108400

3. Karski T. Explanation of biomechanical etiology of the so-called idiopathic scoliosis $(1995$ - 2007). New 276 clinical and radiological classification" in "Pohybove Ustroji". Locomotor System. 2010; 17: 26 - 42.

4. Karski Tomasz. Factores biomechanicos en la etiologia de las escoliosis dinominadas idiopaticas. Nueva 282 clasificacion. Nuevos test clinicos y nueavo tratamento conservador y profilaxis". Cuestiones de Fisioterapia. 2010; 39: 85-152.

5. Karski Tomasz. Biomechanical Etiology of the So-called Idiopathic Scoliosis (1995-2007). New Classification: 285 Three Groups, Four Sub-types. Connection with "Syndrome of Contractures". Pan Arab J Orth Trauma. 2010; 14.

6. Karski T. Biomechanical Etiology of The So-Called Idiopathic Scoliosis (1995 - 2007) - Connection with 279 "Syndrome of Contractures" - Fundamental Information for Paediatricians in Program of Early Prophylactics. / J US-China Med Sci. 2011; 8.

7. Karski Tomasz. Biomechanical Etiology of the So-called Idiopathic Scoliosis (1995 - 2007). Three Groups and 288 Four Types in the New Classification. J Novel Physiotherapies. 2013; 289-290.

8. Karski Jacek, Tomasz Karski. So-Called Idiopathic Scoliosis. Diagnosis. Tests Examples of Children Incorrect 291 Treated. New Therapy by Stretching Exercises and Results. J Novel Physiotherapies. 2013; 3-2.

9. Karski Tomasz. Biomechanical Aetiology of the So-Called Idiopathic Scoliosis. New Classification (1995 - 2007) in Connection with "Model of Hips Movements". Global Journal of Medical Research H: Orthopedic and Musculoskeletal System. 2014; 14.

10. Karski Tomasz. Biomechanical Etiology of the So-called Idiopathic Scoliosis (1995 - 2007) - Connection with "Syndrome of Contractures" - Fundamental Information for Pediatricians in Program of Early Prophylactics. Surgical Science. 2014; 5: 33-38.

11. Karski Tomasz, Karski Jacek. Syndrome of Contractures and Deformities" according to Prof. Hans Mau as Primary Cause of Hip, Neck, Shank and Spine Deformities in Babies. Youth and Adults American Research Journal of Medicine and Surgery. 2015; 1.

12. Karski Tomasz, Jacek Karski. Biomechanical etiology of the socalled Idiopathic Scoliosis (1995 - 2007). Causative role of "gait" and "permanent standing 'at ease' pn the right leg". New classification. Principles of new therapy and causal prophylaxis. Canadian Open Medical Science \& Medicine Journal. 2015; 1: 1-16.

13. Karski Jacek, Tomasz Karski, Jarosław Pyrc, Małgorzata Kulka Deformations of the feet, knees, hips, pelvis in children and adults with minimal brain dysfunction causes treatment. Prophylaxis. 2016.

14. Karski Tomasz, Jacek Karski. Bóle krzyża - problem neurologiczno - ortopedyczny. Objawy. Przyczyny. Leczenie. Back pain - neurologyorthopedic problems. Clinic, causes, therapy and prophylaxis. Postępy Neurologii Praktycznej, Wydawnictwo Czelej. 2016; 9 - 16.

15. Karski Jacek, Karski Tomasz. "Imperfect hips" As a Problem at an Older Age. Early and Late Prophylactic Management before Arthrosis. Jacobs Journal of Physiotherapy and Exercises / USA / Texas. 2016; 1: 7.

16. Karski Tomasz. Physiotherapy- Correct, or Incorrect, Based on 'Wrong
Principles of Treatment'. Example for Spine, Hip, Knee, Shank and Feet. 2017.

17. Karski Tomasz, Jacek Karski, Klaudia Karska, Katarzyna Karska, Honorata Menet. Pediatric Prophylaxis Program of Motor System Deformations and IIInesses in Children. Problems of Spine, Hips, Knees and Feet. EC PAEDIATRICS. 2018.

18. Karski Tomasz, Jacek Karski, Katarzyna Karska, Klaudia Karska, Honorata Menet. Prophylactic Rules for Newborns, Babies, Children and Adults in problems of Hip, Knee, Shank, Feet and Spin. Online J CRIMSON PUBLISHERS. 2018.

19. Karski Tomasz. Biomechanical Aetiology of the So-called Adolescent Idiopathic Scoliosis (AIS). Lublin Classification (1995-2007). Causative Influences Connected with "Gait" and "Standing 'at ease' on the Right Leg". J Orthopaedics Bone Res. 2018.

20. Karski Tomasz. Biomechanical Etiology of the So-called Idiopathic Scoliosis (Adolescent Idiopathic Scoliosis [AIS]). New Classification Rules of Therapy and Prophylaxis. Nurs Health Care J. 2019; 4.

21. Burwell G, Dangerfield PH, Lowe T, Margulies J. Spine Etiology of Adolescent Idiopathic Scoliosis: Current Trends and Relevance to New Treatment Approaches. 2000; 324.

22. Dangerfield PH, Dorgan JC, Scutt D, Gikas G, Taylor JF. Stature in Adolescent Idiopathic Scoliosis (AIS).14 Meeting EPOS, Brussels. 1995

23. Green NE, Griffin PP. Hip dysplasia associated with abduction contracture of the contralateral hip. J Bone Joint Surg Am.1982; 64 1273-1281.

PubMed: https://www.ncbi.nlm.nih.gov/pubmed/7142235

24. Gruca A, Tylman D. Patomechanika bocznych skrzywień kręgosłupa, Wydawnictwo Severus. Warszawa. 1995.

25. Heikkilä E. Congenital dislocation of the hip in Finland. An epidemiologic analysis of 1035 cases. Acta Orthop Scandinavica. 1984; 55: 125-129.

26. Hensinger RN. Congenital dislocation of the hip. Clinical Symp. 1979; 31: 270 .

27. Howorth B. The etiology of the congenital dislocation of the hip. Clin Orthop. 1977; 29: 164-179.

28. Malawski Stefan. Epidemiologia skoliozy, Postępy Polskiej Spondyloortopedii. 1992.

29. Malawski Stefan. Własne zasady leczenia skolioz niskostopniowych Postępy Polskiej Spondyloortopedii. 1992.

30. Malawski S. Własne zasady leczenia skolioz niskostopniowych w świetle współczesnych poglądów na etiologię i patogenezę powstawania skolioz, Chir Narz Ruchu i Ortop Pol. 1994; 3: 189-197.

31. Mau H. Zur Ätiopathogenese von Skoliose, Hüftdysplasie und Schiefhals im Säuglinsalter. Zeitschrift f. 294 Orthop. 1979; 5: 601-605.

32. Mau H. Die Atiopatogenese der Skoliose, Bücherei des Orthopäden, Band 33. Enke Verlag Stuttgart. 1982.

33. Normelly $\mathrm{H}$. Asymmetric rib growth as an aetiological factor in idiopathic scoliosis in adolescent girls, 298. Stockholm. 1985.

34. Rapała K, Tylman D. Patomechanika bocznych skrzywień kręgosłupa, Wydawnictwo Severus, Warszawa. 1995.

35. Stokes IAF. Studies in Technology and Informatics, Research into Spinal Deformities. 1999; 59.

36. Sevastik J, Diab K. Studies in Technology and Informatics, Research into Spinal Deformities. 1997; 37

37. Tylman D. Patomechanika bocznych skrzywień kręgosłupa, Wydawnictwo Severus, Warszawa. 1995.

38. So-called idiopathic scoliosis. 